(C) 1982 ISIJ

\title{
マルテンサイト炭素鋼の焼もどし機構
}

一一電子顕微鏡・電子回折による最近の研究——

長倉 繁榣*·弘津 禎彦*2 楠 美智子*3

鈴木 俊明*4 $\cdot$ 中村 吉男 ${ }^{* 5}$

\section{Tempering Mechanism of Martensitic Carbon Steel} - Recent Studies by Electron Microscopy and Diffraction-

\author{
Sigemaro Nagakura, Yoshihiko Hirotsu, Michiko Kusunoki, \\ Toshiaki Suzukr, and Yoshio Nakamura
}

\section{1. 緒言}

マルテンサイト炭素鋼の㛙もどし機構は古くから研究 され，それには 3 つの段階があることが知られており1), 第 1 段階は $100^{\circ} \mathrm{C}$ 付近，第 2 段階は $280^{\circ} \mathrm{C}$ 付近，第 3 段階は $300 \sim 500^{\circ} \mathrm{C}$ の温度範囲でそれぞれ起こるとされ ている.図 1 は水焼入れした高炭素鋼の昇温比熱曲線 ${ }^{2}$ であるが，これにはこの 3 つの段階が明確に示されてお り, しかも, これらの段階における変化はいずれも発熱 を伴うものであるのが知られる. 図 2 は水焼入れ直後に 液体空素により深冷処理した試料の $-100^{\circ} \mathrm{C}$ からの昇 温比熱曲線2)である。これから， $-100^{\circ} \mathrm{C}$ 以下の温度か ら $90^{\circ} \mathrm{C}$ 付近の温度間でも発熱を伴ら変化が起きている ことがわかる.この発熱は初期発熱2) と呼ばれ，この構 造変化の段階を初期段階2) または（析出の）準備段階1) (Preliminary Stage) と呼ばれる.かくして, マルテン サイト鋼の焼もどし過程は 4 つの段階に区分されること となる.

従来, 燒もどし時に起こる構造変化は主としてX線回 折法により研究されてきた. しかし, 構造変化が極めて 微視的な尺度で起きて拈り，しかも単結晶回折像が得ら れないという事情のため，その詳細は必ずしも明確では なからた，高分解能電子顕微鏡と制限視野電子回折を用 いる方法 (以下電顕法と呼ぶ) は, こうした場合に最適 な研究方法である．以下，本稿では，ほぼこの 10 年間
に筆者らの研究室で行われてきた電顕法によるマルテン サイト鋼の焼もどし機構に関する研究成果を中心に述べ る.

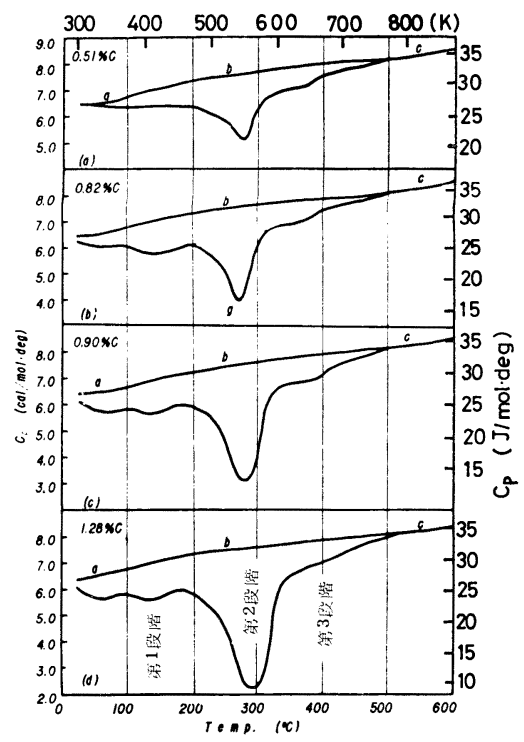

図1 水焼入れした各種マルテンサイト鋼の昇温比 熱曲線1). a b c は焼ならし試料の比熱曲線. 睢和 57 年 7 月 13 日受付 (Received July 13, 1982) (依頼解説)

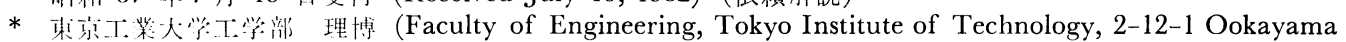
Meguro-ku 152)

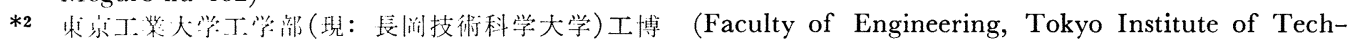
nology, Now The Technological University of Nagaoka)

*3 本宗工桨大学工学部 工愽 (Faculty of Engineering, Tokyo Institute of Technology)

*4 粗京工業大学:工学:部(現：住友金属工業(株)) (Faculty of Engineering, Tokyo Institute of Technology, Now Sumitomo Metal Industries, Ltd.)

*5 涑宗工鄴大兴大学院 (Graduate School, Tokyo Institute of Technology) 


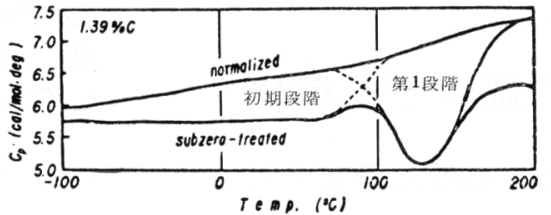

四 2 液体窒素浸漬による深冷処理したマルテンサ イト鋼の昇温比熱曲線1).

\section{2. 試料と観察方法}

帯溶融純鉄 $(99.99 \%)$ 在約 $0.1 \mathrm{~mm}$ 厚に压延し，こ れをメタンと水素の混合ガスにより 900～1050C でほ ほ $2 \mathrm{~h}$ 炭して各種組成の純炭素鋼板をつくり, 高真空 中でオーステナイト化の後, 水焼入れと液体窒素浸漬に よつてマルテンサイト鋼板とした。試料の炭素含有量は マルテンサイトの軸比を測定し, $c / a=1+0.045(\mathrm{wt} \% \mathrm{C}$ ) の関係を用いて決定した. 焼もどしは，通常 $1 \times 10^{-5}$ Torr の高真空中で行つた。 電顕用薄片試料の作製に は, リン酸・クロム酸電解液（液温 $20 \sim 80^{\circ} \mathrm{C}$ ) または 硝酸・メ夕ノール電解液 (液温 $-30^{\circ} \mathrm{C}$ ) を用いる電解 研摩法によつた。なお, この電解研摩は, 初期段階に対 しては，焼もどしの作用も兼礼ている。必要な場合には 薄片化した試料を電顕中で加熱または冷却しつつ観察す るその場観察法も行つている.

\section{3. 初 期 段 階}

Izotov ら) は, 室温で焼もどししたマルテンサイト $\left(\alpha^{\prime}\right)$ の電子回折像中に規則格子斑点とつの状散慢散乱を 認め, これを正方晶炭化鉄 $\mathrm{Fe}_{4} \mathrm{C}$ の析出によるとして説 明した。すた，KHACHATURYAN ら ${ }^{4)}$ はつの状散慢散乱 を炭素原子の短範囲規則化によるとした．筆者らも同様 な観察を行い, 先の結果，初期段階での構造変化は，電 子回折像では，（1 ) 各基本反射点の周りのつの状散慢散 乱の出現，(2)つの状散慢散乱のそれぞれの先端への衛 星斑点の出現，及び $(3) c$ 軸に沿つて 2 つ分裂した規 則格子斑点の出現により特徵つけられることを確認し， それぞれを炭素原子クラスターの形成, 変調 構造の形 成，長範囲規則相の形成によることを実証した。これら の内部構造変化はいずれも炭素原子の再配列に起因する ものである。焼もどし温度が低いので，初期段階では， 鉄原子の移動を伴う構造変化は起きにくい.

\section{$3 \cdot 1$ 炭素原子クラスター}

電顕中で試料を冷却し，残留オーステナイトをマルテ ンサイトに変態させると変態直後からつの状散慢散乱が マルテンサイトの基本反射点の周りに出現するのが観察

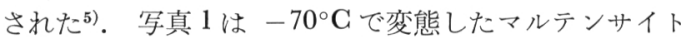
の変態直後の電子回折像である. 散慢散乱は約 $90^{\circ} \mathrm{C}$ 本 で存続し，第 1 段階の変化が始まると消失する. つの状 散慢散乱の逆空間に拈壮る強度分布は図 3 に示すような

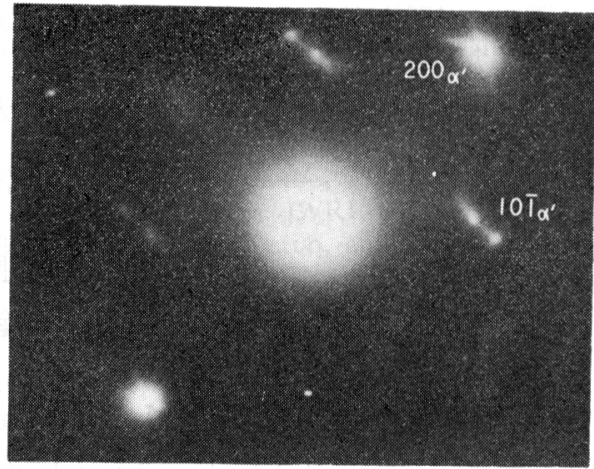

写真 $1-70^{\circ} \mathrm{C}$ で残留オーステナイトの変態によ り生じたマルテンサイトの, 変態直後の電子回折像. 200 基本反射点の周りにつの状散慢散乱が見られる.

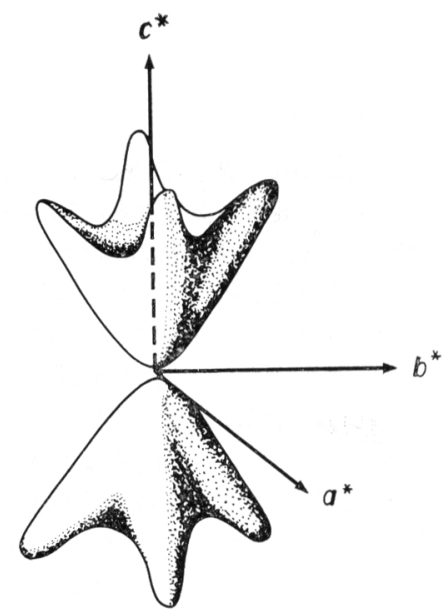

図 3 つの状散慢散乱の逆空間に打ける強度分布. つのの方向は〈102〉*に近い.

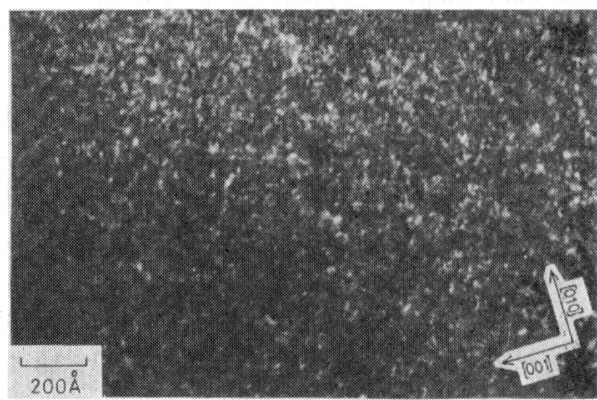

写真 2 つの状散慢散乱を用いて撮影した暗視野電顕 像. 白い斑点は炭素原子クラスター宗す. $1.1 \mathrm{wt} \%$ Gマルテンサイト，電子線入射方向は [100].

もので，つのの方向はだいたい〈102〉*である†. つの 状散慢散乱を用いて暗視野電顕像を撮影すると, 写真 2

$\dagger$ 以後 $[h k l]^{*},\langle h k l\rangle *$ で逆空間における方向, $(u v w) *,\{u v w\}^{*}$ で 逆空間に拈ける面を表す。 
が得られる6). これには径 $10 \AA$ 以下の斑点が無秩序に 分布しているのが見られる. 散慢散乱の解析から, マル テンサイトには $c$ 軸方向に約 $3 \AA, a$ 軸力向に約 $7 \AA$ の 大きさのクラスターの存在が推定されている7)ので，写 真 2 の斑点はクラスターによるものと結論できる， $0^{\circ} \mathrm{C}$ 付近でのクラスターの分布密度は $(2 \sim 4) \times 10^{18} \mathrm{~cm}^{-3}$ で 西り，平均クラスター間距離浊 $60 \sim 80 \AA$ である。な 扣, 次項で述べる変調構造の解析結果によると, 散慢散 乱の強度，すなわち像のコントラストに寄与するのは, 炭素原子ではなく, 主として炭素原子の周りの鉄原子の 変位である。

\section{$3 \cdot 2$ 変調構造8)9}

マルテンサイトの焼戻し温度が $0^{\circ} \mathrm{C}$ 以上になると, つの状散慢散乱の先端に衛星斑点が現れはじめ, 70〜80

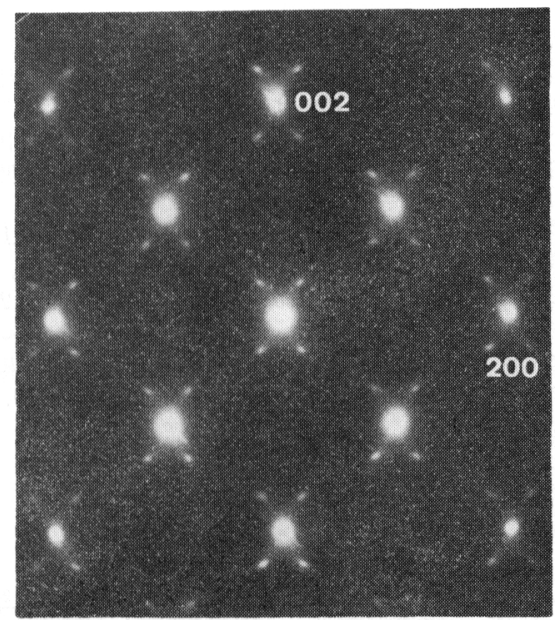

写真 $370^{\circ} \mathrm{C}$ で $1 \mathrm{~h}$ 焼もどした $1.56 \mathrm{wt} \% \mathrm{C}$ マル テンサイトの電子回折像. 各基本反射の周りに衛星 斑点が見られる。

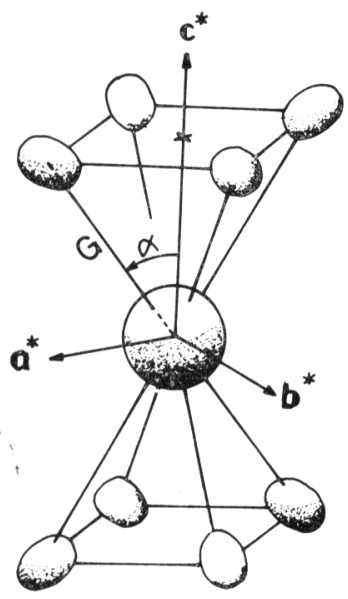

図 4 衛星斑点の逆空間に扮け当強度分布 ${ }^{8}$. つの 状散慢散乱は複雑さ老さけるため画かれていない。

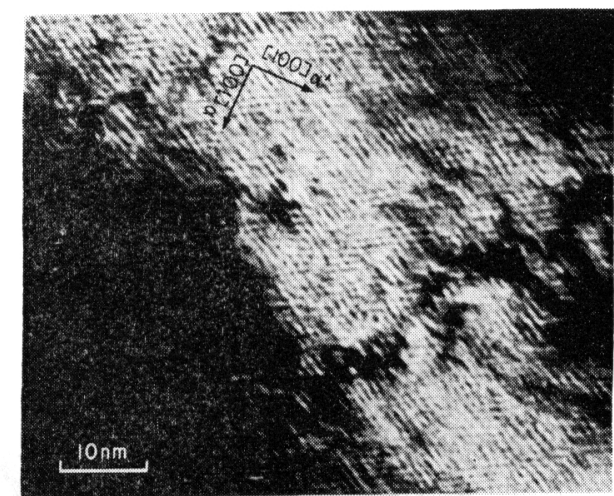

写真 4002 基本反射とその周りの 4 個の衛星斑点 を用いて撮影した变調構造を示寸喑視野電顕像. $70^{\circ} \mathrm{C}$ で $1 \mathrm{~h}$ 焼もどした $1.3 \mathrm{wt} \% \mathrm{C}$ マルテンサイト。 電子線入射方向は [010].

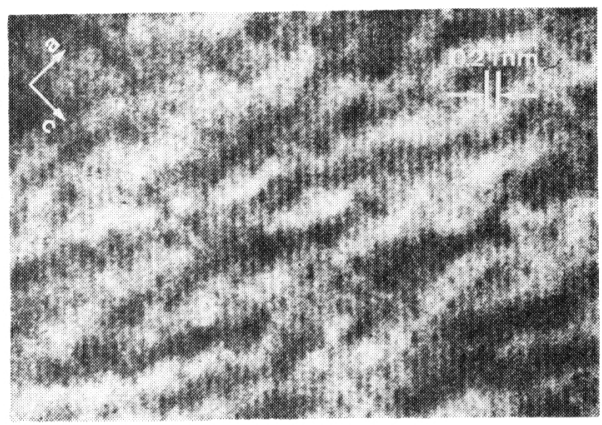

写真 5 変調構造の高分解能電顕像. 細い縦 縞は (101) 面の格子像.ほほ（102) 面に沿つた幅広い縞 は変調構造による。この縞㳗 $10 \AA$ 以下の斑点か らできている． $70^{\circ} \mathrm{C}$ で $1 \mathrm{~h}$ 焼もどした $1.4 \mathrm{wt} \% \mathrm{C}$ マルテンサイト。電子線入射方向は $[0 \overline{1} 0]$.

${ }^{\circ} \mathrm{C}$ で強度最大となり，第 1 段階が始まると消失する. 写真 3 は電子回折写真の一例である. 衛星斑点の強度は 試料の炭素濃度が高い程強いが， $0.2 \% \mathrm{C}$ のものでも観 察された。図4 は衛星斑点の逆空間に和ける分布図で斑 点は $\langle 102\rangle^{*}$ に近い方向に存在する. 写真 4 は 002 基本 反射之，その周りの $(010) *$ 面内にある 4 個の衛星斑点 を用いて結像した暗視野像で，これには医 (120) と (102) 面に沿つて走る間隔 8～9 $\AA$ の縞模様が見られ る. これはマルテンサイトが構造変調を受けたことを示 すものであつて, 縞間隔 $D$ は図 4 の $G$ の逆数, 縞の法線 方向之 $c$ 軸とのなす角は図 4 の角 $\alpha$ に等しい.

写真 4 では縞は交叉して走つているよらに見党るが， 光学変換等により詳細に調べてみると, 広さ $50 \AA$ 位の 領域内では, 縞は一方向にの久走つていることがわか る. 写真 5 は, 基本反射 000 と 101 及びそれらの衛星斑 点を用いて結像させた高分解能電顕像であるが, 間隔 $2.1 \AA$ の (101) 格子面の像のほかに, ほほ (102) 面に沿 つた幅広い縞が見られる。この縞は一様ではなく，大き 

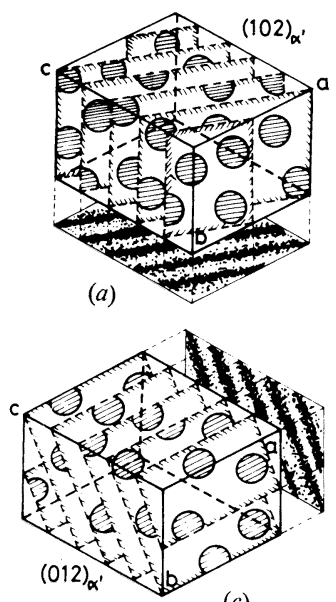

(c)
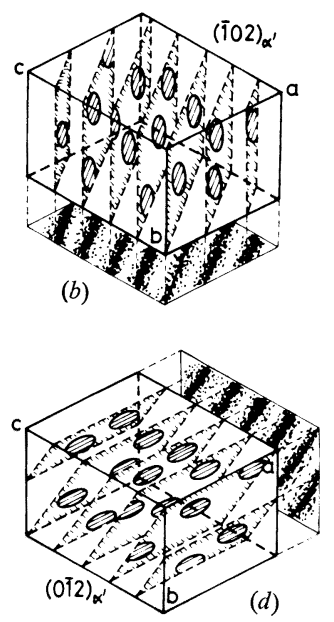

(d)

図 5 変調構造の模式図 ${ }^{9)}$. ( a ), ( b ), ( c ), (d) は可能な 4 つの変調方向に対応する大きさ $50 \AA$ 程 度の分域. 間隔 $10 \AA$ 程度の炭素濃度の商い面の $b$ 軸または $a$ 軸に沿つた投影も画かれている。

さ $10 \AA$ 以下の斑点像よりなり, しかも一方向にのみ走 つている. 更に, 電子線をいろいろな向から入射させ て観察してみると, 電子線が $\{102\}$ 面に平行でないとき は, 写真 2 のような径 $10 \AA$ 以下の斑点が無秩序に分枌 した像が得られる.

以上の事実をふまえて変調構造模型を作ると, 図 5 が 得られる. ここではマルテンサイトの正方対称に応じ て, マルテンサイト結晶は大きさ $50 \AA$ 程度の分域に分 かれており，それぞれの分域内では，大きさ $10 \AA$ 以下 の炭素原子クラスターが注 $\{102\}$ 面内で無秩序に分布 して扣り，そしてこのような炭素濃度の高い面が平均間 隔 $10 \AA$ で整列して変調構造を作つている.

変調構造の詳細を知るため, 衛星斑点の強度を測定し て構造解析を行つた ${ }^{9)}$. その結果を図 6 に示す.これは $1.78 \mathrm{wt} \% \mathrm{C}$ マルテンサイトを $70^{\circ} \mathrm{C} て ゙ 1 \mathrm{~h}$ 焼もどした ものの構造の (010) 投影図で, 大きい丸は鉄原子, 中位 の丸は炭素原子，小さい丸は空な八面体隙間である．鉄 原子に付した矢印はその変位方向（変位量は図の説明支 参照）で，炭素原子は広い八面体隙間に入つている. 変 位量の大きい鉄原子を結ぶと炭素原子 2 個を含む六角形 ができるが，これは写真 5 に拈ける [010] 万问からみた 個々のクラスター像に対応すると考学られる.

各種組成のマルテンサイトを作り, 変調方向 $\alpha$ と変調 周期 $D$ を測定してみると，これらには炭素濃度依存性が あることが判明した ${ }^{9)}$. 図7（a)，（b）にそれらを示 す. 線型弾性論を適用し, 炭素原子侵入に基つく格子卒 みが最少になる方向を計算してみると, 得られた結果は 実測の変調方向をだいたい説明する5)。炭素原子が八面 体隙間に入ると，マルテンサイトは $c$ 軸方向に伸長し，

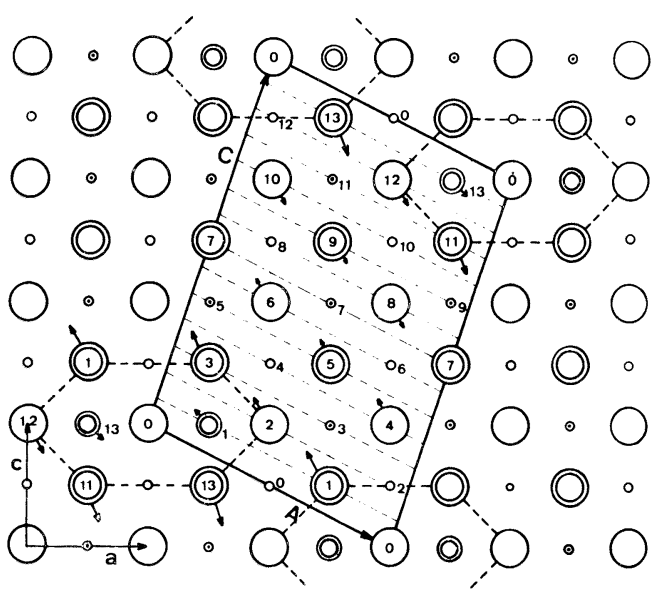

図 6 変調構造の解析結果を示すマルテンサイトの (010)投影図 ${ }^{9)}$. $1.78 \mathrm{wt} \% \mathrm{C}$ マルテンサイト。大き

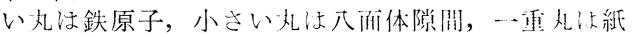
面上に，二重丸は紙面からb/2 だけ下にある。惝

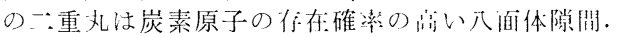
矢印源子の変位方向. 変位显以以下のと打り, 鉄 原子: No. 0, 変位せず; No. $1 J x_{\mathrm{i}} a=-3.1, J z_{1} c$ $=+16.4$; No. $2-4.0$, +7.2; No. $3-3.5$, + 12.3; No. $4-1.9$, +8.3; No. $5-2.0$, +7.2; No. $6-2.2,+4.1 ;$ No. 7 変位せず; No. 8〜 13

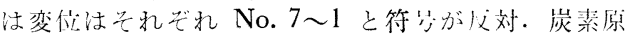
子: No. $1-1.1$, +0.9; No. $13+1.1,-0.9$. 舀位は $10^{-2} \AA$.
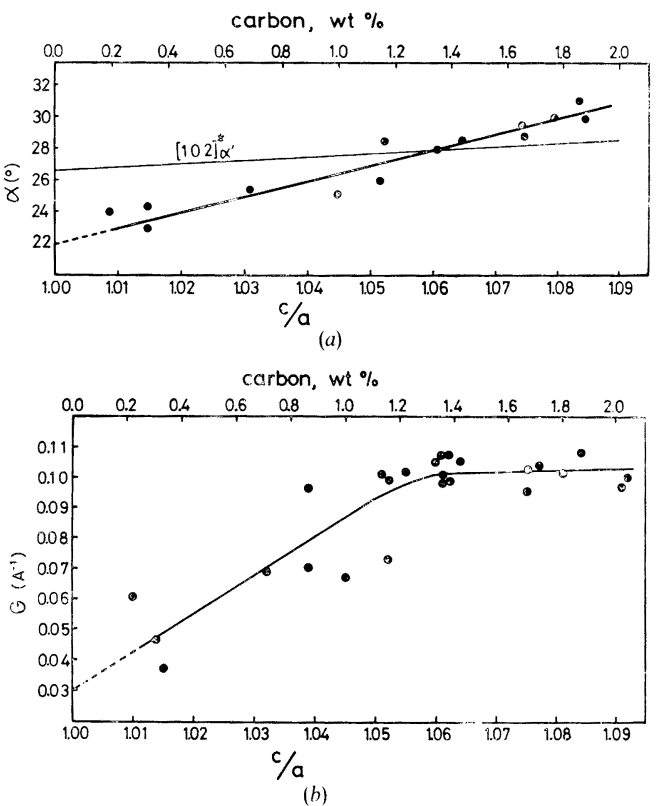

図 7. 变淍角 $\alpha$ と变洞周期の逆数 $G=1 / D$ 菼素濃 度依存性 ${ }^{9}$. 
$a$ 軸方向飞収縮するといら非等方格子歪みが 発生する が，こ机が変調方向を $c$ 軸方向から回転させる原因であ る. WEN ら ${ }^{10)}$ も同様な結果を発表している. 変調周期 についてはまた゚説明がつけられていない。

\section{$3 \cdot 3$ 長周期規則相11)}

マルテンサイトを $60 \sim 80^{\circ} \mathrm{C}$ で焼もどすと規則格子斑 点が衛星斑点とともに出現する. 写真 6 亿命の一例を 示す。この規則格子斑点は, IzoTov $ら^{3)}$ の観察之異な つて, $c^{*}$ 軸方向飞沿つて 2 つ分裂している. 強度は衛 星斑点とくらべてたいいん弱く，しかも強い電子線照射 によつて消失してしまう。これから規則相と変調構造と の一応の区別がつけられる.

図 8 は格子定数 $a^{\prime}=\sqrt{2} a, c^{\prime}=c$ をるつ Izotov らの $\mathrm{Fe}_{4} \mathrm{G}$ 構造模型 3$)$ である。彼らは, 炭素原子は八面体隙

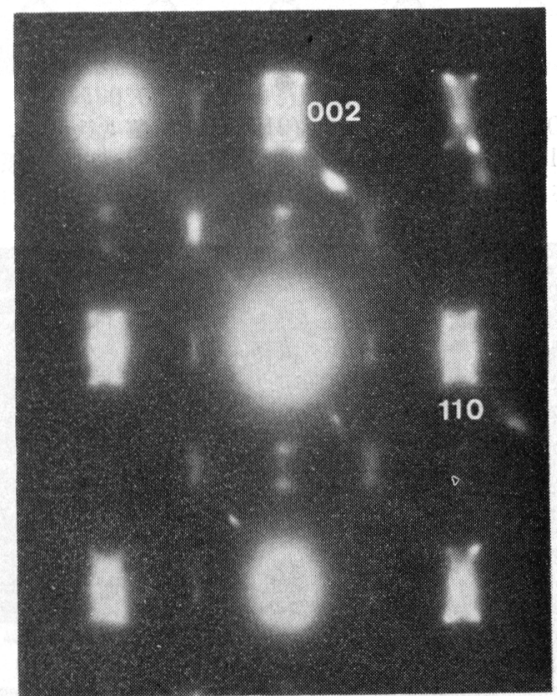

军真 $6 \quad 60^{\circ} \mathrm{G}$ で $1 \mathrm{~h}$ 焼もどした $1.6 \mathrm{wt} \% \mathrm{C}$ マルテ ンサイトの電子回折像. 規則格子反射が $[001] *$ 方 向に 2 つに分裂している。電子線入射方向は [11̄0].

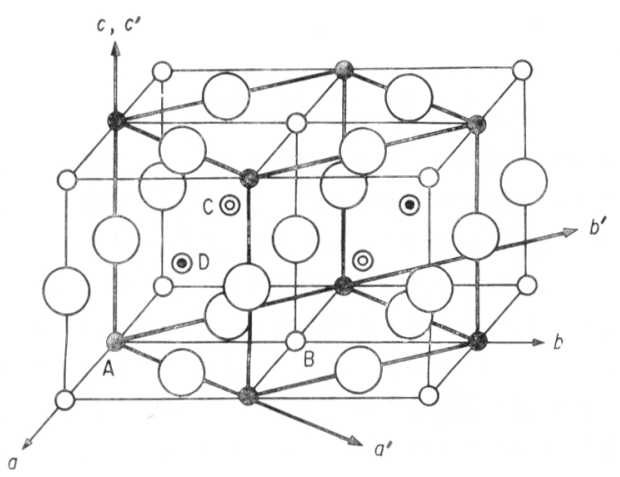

図 8 Izotov らによる $\mathrm{Fe}_{4} \mathrm{C}$ 構造模形。大きい丸 注鉄原子，小さい丸 $\mathrm{A}, \mathrm{B}, \mathrm{C}, \mathrm{D}$ 法八面体隚間, $a^{\prime}=$ $\sqrt{2} a, c^{\prime}=c$.

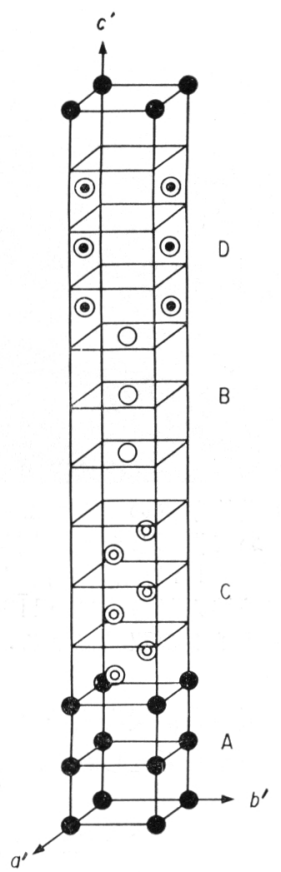

図 9 長周期規則相の模造模型11)。複雑さ怘さける ため，炭素原子のみ示してある， A , B , C , D は図 8 の A, B , C, D と対応寸る. $a^{\prime}=\sqrt{2} a, c^{\prime}=12 c$.

間 $\mathrm{A}$ の々存在するとしたが，これでは規則格子斑点の 分裂を説明できない。この構造に扮いて， B ， C , D 子 $\mathrm{A}$ 之等価な八面体隙間であり, 炭素原子の占めうる位置 で每る。矢れで，A， B， G，D各位置に炭素原子をい ろいろと分布させ，観察事実を説明でさる構造模型をさ がした。 その結果, 図 9 亿示すものが観察事実を最もよ く説明した．ここでは，炭素原子が $c$ 軸に沿ら原子列の いずれにも 3 個ずつ連続して存在しており, 炭素原子の 侵入に伴う格子歪みが各原子列で等しいようになつてい る. この長周期規則相は格子定数 $a^{\prime}=b^{\prime}=\sqrt{2} a, c^{\prime}=$ $12 c$ の斜方結晶である.

長周期規則相の組成は $\mathrm{Fe}_{4} \mathrm{C}$ であるから，无の格子定 数は，母相のマルテンサイトのそ扎には低存せず，常に 一定であるはずである。ところが，実際には， $c^{\prime}=12 c$ であつて, 、ルテンサイトの格子定数, すなわち炭素含 有量飞応じて変化する，この事実は，規則相の組成が母 相のマルテンサイトの組成と余り変らないことを示唆す る. そこで, 図 9 の炭素原子の長周期規則配列模型飞拉 いて，炭素原子の代り空孔子点を，空孔子点の代わり に平均炭素濃度に対応した炭素原子を㨟いた空孔子点の 長周期規則配列模型を考光る. 光学に和ける Babinet の原理により，この構造も前と同じ強度分布を与兄る。 しかも，空孔子点の周りの鉄原子の変位は炭素原子の周 りの炎れよりも小さくてょい，关れ故，この空孔子点の 


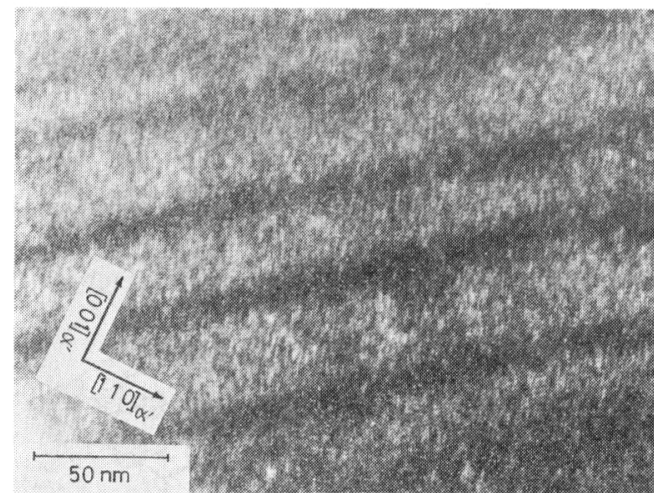

写真 $7 \frac{1}{2} \frac{1}{2} 1$ 逆格子点の周りで $2 つ に$ 分裂した規 則格子反射它用いて撮影した長周期規則相の暗視野 電影像 ${ }^{11)} .60^{\circ} \mathrm{C}$ で $1 \mathrm{~h}$ 焼もどした $1.6 \mathrm{wt} \% \mathrm{C}$ マル テンサイト。電子線入射方向は [1 10$]$. 黑い带状の 領域はマルテンサイトの双晶による.

長周期規則配列模型の方が炭素原子の長周期規則配列模 型よりも妥当性があると考学られる，今後の検討課題で ある。

写真 7 は，逆格子点 $\frac{1}{2} \frac{1}{2} 1$ の周りで, 二つに分裂し ている規則格子反射を用いて撮影した暗視野電顕像であ る。規則相はだいたい $15 \times 100 \AA 2$ の針状の像を与兄， 針の方向は $c$ 軸汶して約 $15^{\circ}$ 傾いている. 分布密度 は $(1 \sim 6) \times 10^{17} \mathrm{~cm}^{-3}$ で，針間の平均距離は $150 \sim 200$ ^である。な拈，この相と変調構造との間の関係はま だ不明である。

\section{4. 第 1 段 階}

燒もどし第 1 段階の変化は $100 \sim 200^{\circ} \mathrm{C}$ で起こり，そ こでは, マルテンサイトの炭素含有量によらずに, 斜方 晶系の炭化鉄 $\eta-\mathrm{Fe}_{2} \mathrm{C}$ が析出する12) 15). 以前, JACK の $\mathrm{X}$ 線回折研究 ${ }^{16)}$ により, 析出物は六方晶系の炭化鉄 $\varepsilon$ $-\mathrm{Fe}_{2}{ }_{3} \mathrm{C}$ とされてきたが, 単結晶電子回折像の精密解析 から, 析出物は $\mathrm{Co}_{2} \mathrm{C}, \mathrm{CO}_{2} \mathrm{~N}$ と同型のもので, 格子定数 $a=4.71, b=4.33, c=2.84 \AA$ を歹, 空間群P Pnm に 属することが証明された。図10亿先の結晶構造を示す。 炭素原子は八面体隙間の半分淔線状並儿で存在し, 鉄原子は，それ応じて，六方最密充填配列からずれた 位置存在寸る。

$\eta-\mathrm{Fe}_{2} \mathrm{C}$ の析出飞伴い, 母相格子定数 $a=2.854$, $c=2.877 \AA$ の低炭素マルテンサイト $\left(\alpha^{\prime \prime}\right)$ 飞移行す

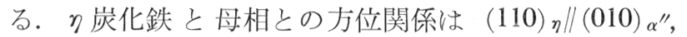

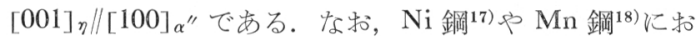
いても， ク炭化鉄が析出することが報告されている.

写真 8 は炭化鉄の暗視野電顕像である。径 $50 \AA$ く らいの粒子が整列して析出しているのが見られる．析出 場所以転位などの格子欠陥之は無関係である。焼もどし 温度が高いと, 個々の粒子が合体して針状になる傾向が

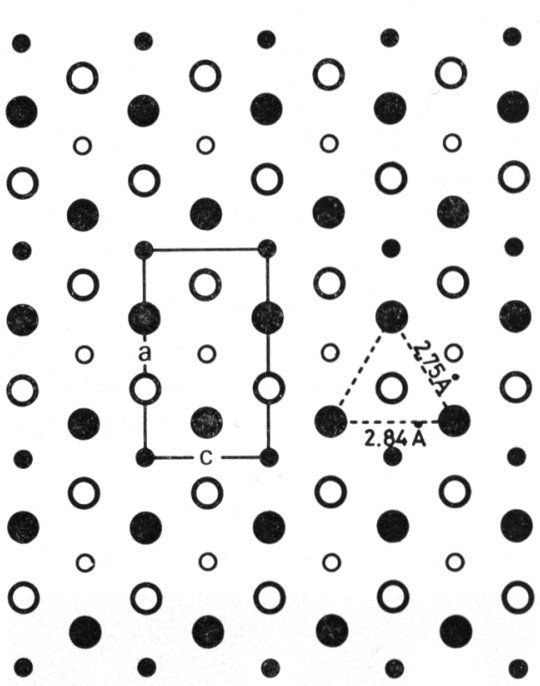

図10 $\eta-\mathrm{Fe}_{2} \mathrm{G}$ の構造の $(010)$ 投影. ：鉄原子, 高 さ $1 / 4 b ; \bigcirc$ : 鉄原子, 高さ $3 / 4 b ;$ : : 炭素原子 高さ $0 ;$ 。炭素原子, 高さ $1 / 2 b$.

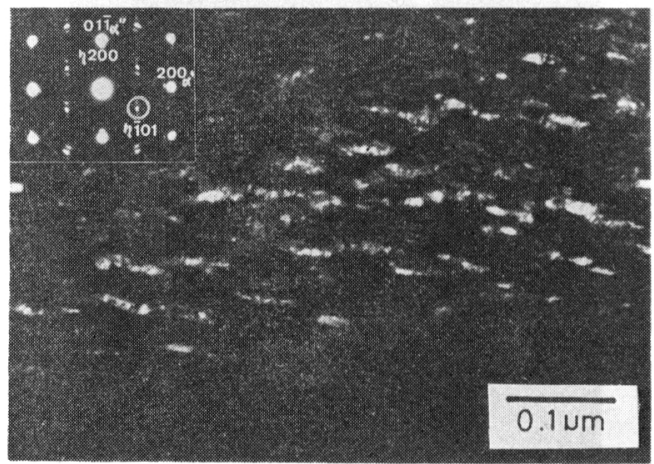

写真 $8200^{\circ} \mathrm{C}$ で $1 \mathrm{~h}$ 焼もどしたマルテンサイト中 の $\eta-\mathrm{Fe}_{2} \mathrm{C}$ の暗視野電顕像と電子回折像. 電子線 入射方向は $[01 \overline{1}]_{\alpha}$. . 電顕像は○印走つけた $101_{\eta}$ 反射学用いて撮影。

ある、

\section{5. 第 2 段 階}

第 2 段階は $280^{\circ} \mathrm{G}$ 付近の温度で起こり, 残留オース テナイトが分解する過程である。この段階で問題となつ ていたのは, 分解過程で $\varepsilon(\eta)$ 炭化鉄が出現するかどう かといらことであつた．X線回折法はこの問題汶して 明確な解答を与党ることはできない。なぜならば，残留 オーステナイトはマルテンサイトと混在して打り，X線 束はその両者を通過するので, 回折像に現れた回折線が 焼もどしマルテンサイトに由来するものか, 分解した オーステナイトに由来するものかの判別が不可能だから である.

この問題は, 電顕その場観察法により, 残留オーステ 


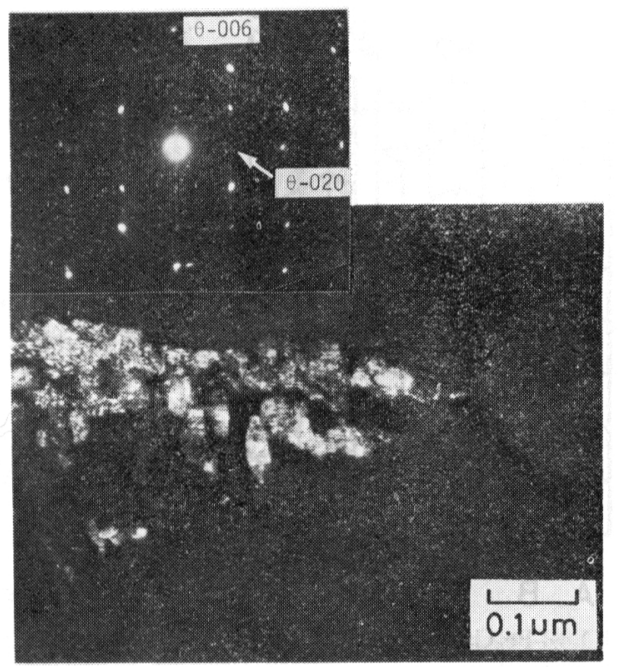

写真 $9190^{\circ} \mathrm{C}$ で分解中の残留オーステナイト粒内 に生じた $\theta-\mathrm{Fe}_{3} \mathrm{C}$ の暗視野電顕像々電子回折像. 電 顕像は $020_{\theta}$ 反射(矢印) を用いて撮影. 電子線入射 方向は $[100]_{\theta}$.

ナイトの分解過程を観察すれば完全に解決できる. それ で, 高温試料ホルダーに, 水燒入れ後電解研摩した薄片 をセットし，いろいろな温度に保持しつつ残留オーステ ナイトの分解過程を連続観察した. その結果, $190^{\circ} \mathrm{G}$ 付 近の比較的低温では, 分解は残留オーステナイトと焼も どしマルテンサイト $\left(\alpha^{\prime \prime}+\eta\right)$ との境界より出発し, 次 いで分解領域がオーステナイト中をくさび状に突出して ゆくこと, 及び $230^{\circ} \mathbf{C}$ 以上ではオーステナイト中から も分解が開始することが観察された ${ }^{19)}$. 写真 9 は分解中 の電顕写真の一例である. 分解生成物は $\theta-\mathrm{Fe}_{3} \mathrm{C}$ 之 $\alpha$ 鉄のみであり, $\varepsilon(\eta)$ 炭化鉄は形成されない, $\theta-\mathrm{Fe}_{3} \mathrm{G}$ 粒子は径 $500 \AA$ 程度の粒状の形態をもち， $\alpha$ 鉄中に Bagaryatsukii の方位関係 ${ }^{20)} \quad(100)_{\theta} / /(011)_{\alpha} / /(111)_{\gamma}$, $[010]_{\theta} / /[11 \overline{1}]_{\alpha} / /[10 \overline{1}]_{\gamma}$ をとつて分散しているが，关の 内部には $(001)_{\theta}$ 面に平行な構造欠陥を含んでいる.

分解前の残留オーステナイトの電子回折像に, 特微あ る散慢散乱が基本反射のまわりに観察され，それを用い て撮影した暗視野電顕像には径 $10 \AA$ 以下の大きさの斑 点が分布しているのが観察された ${ }^{21)}$. これから残留オー ステナイト中にも炭素原子クラスターが形成されること が知られた，その詳細はまだ不明であるが，3.1で述べ たマルテンサイト変態直後に見られるクラスターと関係 するのではないかと想像される.

\section{6. 第 3 段 階}

マルテンサイトを焼もどしたとき，最終的に生成され るものは $\theta-\mathrm{Fe}_{3} \mathrm{G}$ と $\alpha$ 鉄であることは古くから知られ ている. しかし, 第 3 段階の初期に拈いて, 単斜晶系の 炭化鉄 $\chi-\mathrm{Fe}_{5} \mathrm{C}_{2}$ が出現するか否かが以前から問題とさ
れていた。 X線回折法はこの問題解決にはあまり有力で はない. といらのは $\theta-\mathrm{Fe}_{3} \mathrm{C}$ 之 $\chi-\mathrm{Fe}_{5} \mathrm{C}_{2}$ の粉末回折像 は極めて類似しているからである。 また，制限視野電子 回折法による研究で, 回折像中に $\chi-\mathrm{Fe}_{5} \mathrm{C}_{2}$ で指数づけ ができるものがあることから， $\chi-\mathrm{Fe}_{5} \mathrm{C}_{2}$ が形成されると いら説22) が出されたが，その回折像には $\chi-\mathrm{Fe}_{5} \mathrm{C}_{2}$ では 出現しない回折斑点が多数含まれているので, 単純に $\chi$ $\mathrm{Fe}_{5} \mathrm{C}_{2}$ が析出しているとはいいきれない，他方，析出物 の電顕像中は $\theta-\mathrm{Fe}_{3} \mathrm{C}$ の (001) 面に平行な縞模様が観察 されたので，析出物は $\chi-\mathrm{Fe}_{5} \mathrm{C}_{2}$ ではなく，面欠陷を多数 含む $\theta-\mathrm{Fe}_{3} \mathrm{C}$ にすぎないといら説23) も提出されている.

こうした問題は, 高分解能電顕の格子像法, 構造像法 を採用し，析出物の構造を原子的尺度で観察することに より解決できる ${ }^{24)}$. その結果，第 3 段階の初期 $\left(400^{\circ} \mathrm{C}\right.$ 以下）では，析出物は $\theta-\mathrm{Fe}_{3} \mathrm{C}, \chi-\mathrm{Fe}_{5} \mathrm{C}_{2}$, 高次炭化鉄 $\theta_{n}-\mathrm{Fe}_{2 n+1} \mathrm{C}_{n}(n \geqq 3)$ の薄層が microsyntactic intergrowth したものであることが判明した. ここで, microsyntactic intergrowth とは，類似の結晶構造をも つ幾つかの相が，との成長軸を共通にして微視的尺度で 混合している結晶成長様式である.

図 11 ( a ) と (b) に，それぞれ $\theta-\mathrm{Fe}_{3} \mathrm{G}$ と $\chi-\mathrm{Fe}_{5} \mathrm{C}_{2}$ の結晶構造の (100) 投影, (010) 投影を示す。 これらの 結晶に括いては，6個の鉄原子の作る三角プリズム型配 位多面体（その中心炭素原子が存在する）がその角や 稜を共有して作るプリズム層があり, それらが積層し て結晶を作っていると見なせる。プリズム層には互に $180^{\circ}$ 回転した関係にある $\mathrm{A}$ 層と $\mathrm{B}$ 層とがあるから， $\theta$ $\mathrm{Fe}_{3} \mathrm{C}$ の構造に和忊る積層は， $\mathrm{A}|\mathrm{B}| \mathrm{A}|\mathrm{B}| \cdots \cdots$ と かけ， $\chi-\mathrm{Fe}_{5} \mathrm{C}_{2}$ の炎れは $|\mathrm{AB}| \mathrm{AB}|\mathrm{AB}| \cdots \cdots$ と かける，ここで，繸棒はプリズム層間にギャップがある ことを意味し，また $\mathrm{AB}$ は $\mathrm{A}$ 層と $\mathrm{B}$ 層とが連結した二 重プリズム層を意味する，プリズム層の厚さは $2.5 \AA$ で, $\theta-\mathrm{Fe}_{3} \mathrm{C}$ では層間ギャップが $0.9 \AA$ なので積層周 期は $3.4 \AA\left(=\frac{1}{2} c_{\theta}\right), \quad \chi-\mathrm{Fe}_{5} \mathrm{G}_{2}$ ではギャップが $0.8 \AA$ なので積層周期は $5.8 \AA\left(=\frac{1}{2} a_{\chi} \sin \beta, \beta=97.7^{\circ}\right.$ は軸 間角）となる. 一般に $n$ 重連結したプリズム層をもつ炭 化鉄 $\theta_{n}=\mathrm{Fe}_{2 n+1} \mathbf{C}_{n}$ を考光れぱ，その積層は | A B A $\cdots \cdots \mid{ }_{n} \cdots \cdots$ となり，積層周期は萎添 $(2.5 n+0.8) \AA$ である.これらの炭化鉄はいずれも類似した構造をもつ ので，プリズム層に垂直な方向に microsyntactic intergrowth することができる.

写真 10 はマルテンサイトを $400^{\circ} \mathrm{C} て ゙ 1 \mathrm{~h}$ 焼もどした 之きの析出粒子の積層面の格子像である. 炭化物粒子は 抽出レプリカ法により母相 $\alpha$ 鉄から分離してある. これ から, $400^{\circ} \mathrm{C}$ 焼もどし時に析出した粒子内では, $\theta-\mathrm{Fe}_{3} \mathrm{C}$ と $\chi-\mathrm{Fe}_{5} \mathrm{C}_{2}$ とが microsyntactic intergrowth している のが知られる. 写真 11 はやはり $400^{\circ} \mathrm{C}$ 逽もどし時の 析出粒子の構造像で, $\theta-\mathrm{Fe}_{3} \mathrm{G}$ と $\chi-\mathrm{Fe}_{5} \mathrm{C}_{2}$ のmicrosyntactic intergrowth を示すものである. 写真で白点は 

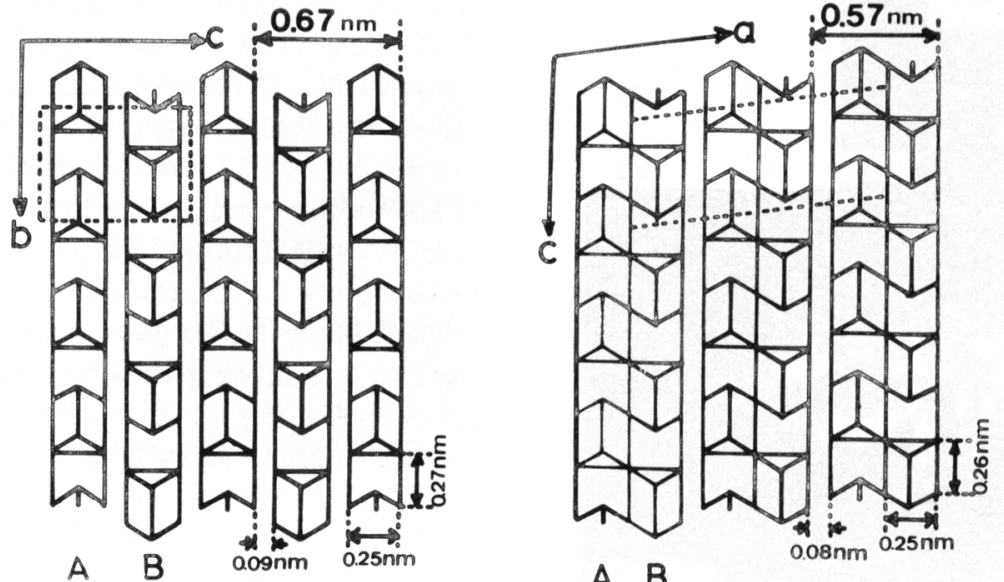

図11（a） $\theta-\mathrm{Fe}_{3} \mathrm{C}$ の構造の (100) 投影, (b) $\chi-\mathrm{Fe}_{5} \mathrm{C}_{2}$ の構造の (010) 投影. 炭素原子はプリズムの浪济中央にあるが，示されていない。

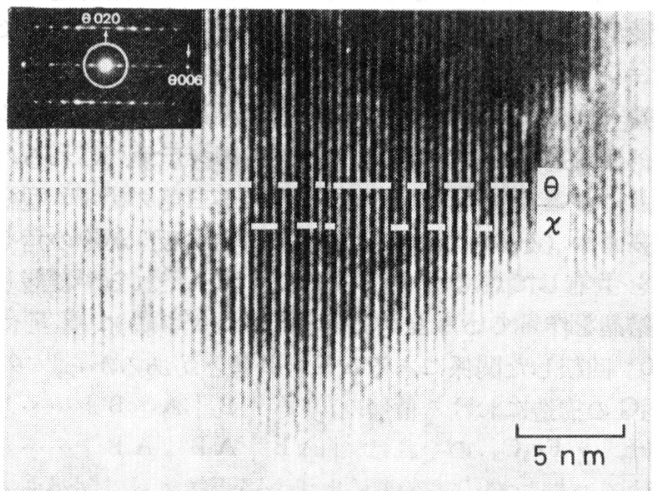

写真 $10400^{\circ} \mathrm{C}$ で $1 \mathrm{~h}$ 焼もどしたマルテンサイト中に 生じた炭化鉄粒子の格子像之電子回折像. $\theta-\mathrm{Fe}_{3} \mathrm{C}$ 子 $\chi-\mathrm{Fe}_{5} \mathrm{C}_{2}$ の microsyntactic intergrowth が見られる。 (縞間隔: $\theta-\mathrm{Fe}_{3} \mathrm{C}$ は $6.7 \AA, \chi-\mathrm{Fe}_{5} \mathrm{C}_{2}$ は $5.7 \AA$ ). 電子線入射方向は $[100]_{\theta}$.

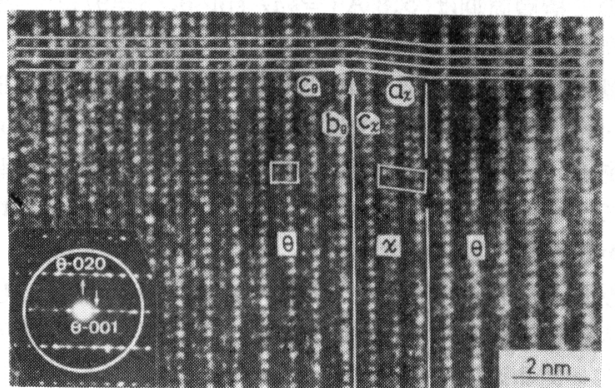

写直 $11400^{\circ} \mathrm{C}$ で $1 \mathrm{~h}$ 恎もどしたマルテンサイト中 に生じた炭化鉄粒子の構造像 ${ }^{24)}$. 黑い部分は鉄原子 のあるところに, 白い玟点は鉄原子間の隚間に刘応 する。単位格子が平行四辺形で示されている。附置 の電子回折像中の白丸内の反射が電顕像撮影见用い られている。電子線入射方向は $[100]_{\theta}$.

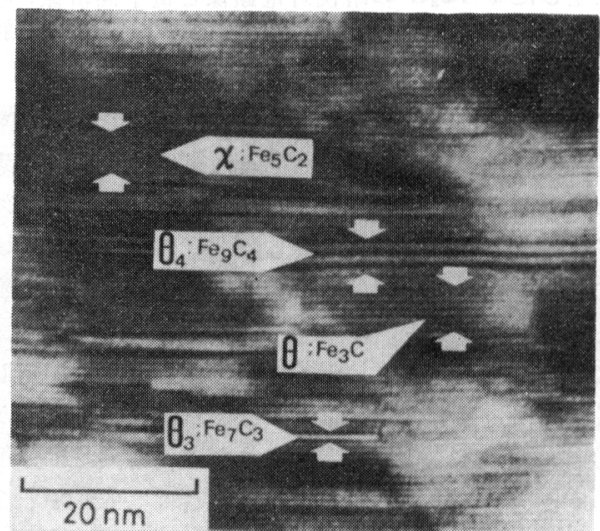

写真 $12270^{\circ} \mathrm{C}$ で $1 \mathrm{~h}$ 焼もどしたマルテンサイト中 の炭化鉄䊀子の格子像 ${ }^{24)}$. 各種炭化鉄の microsyntactic intergrowth が見られる。電子線入射方向 は $[100]_{\theta}$.

プリズムの中間を示し，暗い部分は鉄原子のある部分 で，分解能不足のため鉄原子は分離観察されていない. これらのことはイメージ・シミュレーションにより確か められている ${ }^{2425)}$. なお，回折像には [001]当方に走 るストリークが見られるが，これも $\theta-\mathrm{Fe}_{3} \mathrm{C}$ と $\chi-\mathrm{Fe}_{5} \mathrm{C}_{2}$ の microsyntactic intergrowth に起因するものである. 燒もどし温度が $270^{\circ} \mathrm{C}$ に下がると，電顕像はより複 雑なものとなる。写真 12 はその一例で, $\theta-\mathrm{Fe}_{3} \mathrm{C}$ と $\chi-\mathrm{Fe}_{5} \mathrm{C}_{2}$ の他に，より積層周期の大きな縞が見られる. これらは高次炭化鉄 $\theta_{3}-\mathrm{Fe}_{7} \mathrm{C}_{3}, \theta_{4}-\mathrm{Fe}_{9} \mathrm{C}_{4}$ 等の intergrowth 層として説明できる. 回折像中にも，高次炭化 鉄の積層周期に対応した回折斑点が観察されている。

焼もどし温度が $450^{\circ} \mathrm{C}$ 以上になると，折出粒子は $\theta-\mathrm{Fe}_{3} \mathrm{C}$ のみよりなる。ただし，わずかだが，構造欠陥 


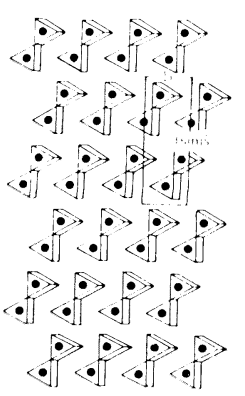

(a)

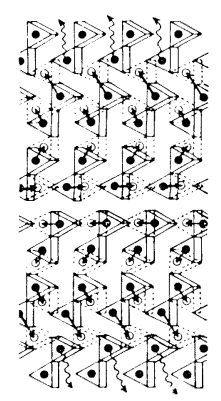

(b)

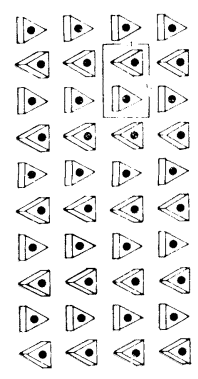

(c)
図 $12 \chi-\mathrm{Fe}_{5} \mathrm{C}_{2}$ 出ら $0-\mathrm{Fe}_{3} \mathrm{C}$ 一变態機構

(本交参照).

は含まれている。

以上述べたごとく, 第 3 段階の初期では， $\theta-\mathrm{Fe}_{3} \mathrm{C}, \chi^{-}$ $\mathrm{Fe}_{5} \mathrm{C}_{2}, \theta_{n}-\mathrm{Fe}_{2 n+1} \mathrm{C}_{n}$ が析出粒子内に intergrowth 乙 ているが，温度上算と共に，まず $\theta_{n}-\mathrm{Fe}_{2 n+1} \mathrm{C}_{n}$ が消失 し, 次いで $\chi-\mathrm{Fe}_{5} \mathrm{C}_{2}$ が消失して, 最終的には析出粒子 は $\theta-\mathrm{Fe}_{3} \mathrm{C}$ の文からなるように変化する。この変化は その場変態 (in-situ transformation) である. その機構 を $\chi-\mathrm{Fe}_{5} \mathrm{G}_{2} \rightarrow \theta-\mathrm{Fe}_{3} \mathrm{G}$ を例として画いたのが図 $12(\mathrm{a})$, (b)，(c) である24).（a ) $\chi-\mathrm{Fe}_{5} \mathrm{G}_{2}$ の構造の $c$ 面投 影, (c) は $\theta-\mathrm{Fe}_{3} \mathrm{C}$ の構造の $b$ 面投影で, 黑丸が炭素原 子を衣与（（b)にホす上らに， $\chi-\mathrm{Fe}_{5} \mathrm{C}_{2}$ 中の炭素原子が 黑丸の位置から白丸の位㩐に移動すれば， $\chi-\mathrm{Fe}_{5} \mathrm{C}_{2}$ のプ リズム羱の二重連結は切れて単層となる.この構造にお いて鉄原子が $[001] x$ 方向に動き, さらに $[100] x,[010] x$ 方向にもわずかに動けば $\theta-\mathrm{Fe}_{3} \mathrm{C}$ の構造ができあがる. この変態では，炭素原子が余分になるが，これら余分な 炭素原子は粘子の衣面に抎散し，粒の成長に容与すると 考兄られる。この変態機構は原子の長距離抎散を必要と せず, 従つて析出䊀子の形態や体積には余り大きな変化 を与えないので，时相 $\alpha$ 鉄中で円滑に進行できる.な お， $\chi \rightarrow \theta$ 転移が起こることは, 蒸着薄膜を渗炭して作 つた炭化鉄溥膜のその埸菴子可折研究 ${ }^{26)} て ゙$ 尖際に確かめ られている.

本節の初めに述べた $\chi-\mathrm{Fe}_{5} \mathrm{C}_{2}$ によるとして説明でき ない回折斑点の出現 ${ }^{22)}$ は, $\chi-\mathrm{Fe}_{5} \mathrm{C}_{2}$ と $\theta-\mathrm{Fe}_{3} \mathrm{C}$ との microsyntactic intergrowth に起因するものである.す なわち，入射電子力问が intergrowth 層と平行でない ときは， $\chi-\mathrm{Fe}_{5} \mathrm{C}_{2}$ の薄層で间折された電子は $\theta-\mathrm{Fe}_{3} \mathrm{C}$ 薄 層で再び回折される, あるいはその逆の過程により，炭 化鉄薄層間での二重回折による斑点が出現せねばならな いからである24)。 また，析出物が面欠陷を含さ $\theta-\mathrm{Fe}_{3} \mathrm{C}$ であるといら説23)の面欠陷は $\chi-\mathrm{Fe}_{5} \mathrm{C}_{2}$ などの薄層であ ると考えてよい，この説は電顕の分解能の不足のために 生じたものである。

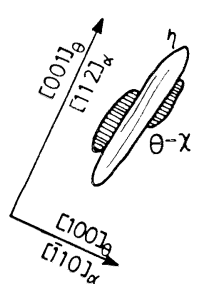

(a)

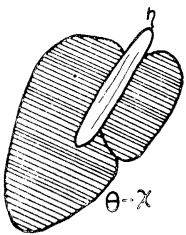

(b)

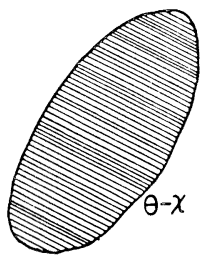

(c)
网 13 第 1 段階から符 3 段階一の遷移. (a) $\eta-\mathrm{Fe}_{2} \mathrm{C}$ 䊀子の界面一の $\theta$ 系炭化鉄の核発生. (b) $\theta$ 采炭化 鉄䊀子の成厓. (c) $\eta-\mathrm{Fe}_{2} \mathrm{C}$ の消失々 $\theta$-系炭化鉄粒 子の今体.

\section{7. 第 $\mathbf{1}$ 段階から第 $\mathbf{3}$ 段階への遷移過程}

第 1 段階での組織は $\eta-\mathrm{Fe}_{2} \mathrm{G}$ と $\alpha^{\prime \prime}$ よりなり, 第 3 段階でのそれは $\theta-\mathrm{Fe}_{3} \mathrm{C}, \chi-\mathrm{Fe}_{5} \mathrm{C}_{2}, \theta_{n}-\mathrm{Fe}_{2 n+1} \mathrm{C}_{n}$ (以下 $\theta$ 系炭化鉄と呼ぶ）と $\alpha$ 鉄よりなる。 そこで，どのよう な機構でこの遷移が起こるかが問題となる。これに関 乙, $\theta$ 系炭化鉄は母相 $\alpha^{\prime \prime}$ の双晶境界に核発生するとい う説, $\eta(\varepsilon)$ 炭化鉄内の双晶境界に核発生するという説, あるいは $\eta(\varepsilon)$ 炭化鉄が母相に溶解し, 新たに $\theta$ 系炭 化鉄が核発生するといら説などがある. マルテンサイト を $200^{\circ} \mathrm{C}$ 近傍の温度で 1 10 日焼もどして, 高分解能電 顕法により調べた結果，遷移過程は次のごとくであこと

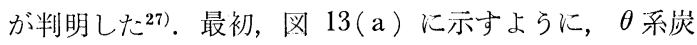
化鉄粒子（主として $\theta-\mathrm{Fe}_{3} \mathrm{C}$ と $\chi-\mathrm{Fe}_{5} \mathrm{C}_{2}$ とが microsyntactic intergrowth したもの) が $ク$ 一炭化鉄粒子の界面 に形成される（図のよらにり炭化鉄粒子の両側に形成さ れることがしばしばある)。この $\theta$ 系炭化鉄は母相 $\alpha^{\prime \prime}$ (又は $\alpha)$ と Bagaryatsukii の方位関係 ${ }^{20)}$ を持つている

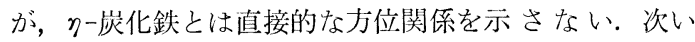
で，(b)のように， $\theta$ 系炭化鉄粒子は $\eta$ 炭化鉄粒子を残 したまま成長する，この成長は $\alpha^{\prime \prime}$ 中の炭素を取り込む ことによつて進行すると考えられる. 成長は母相と整合 性のよい $b_{\theta}, c_{\theta}$ 方向には進行しやすいが，整合性の恶 い $a_{\theta}$ 万向には進行しにくいので，粒子は $a_{\theta}$ 軸方向に 薄い扁平状のものとなる. 最後に, ( c ) のごとく, ク炭 化鉄が分解して $\theta$ 系炭化鉄に組及込末れる．また，相接 した $\theta$ 系炭化鉄粒子も合体し，第 3 段階初期に見られた $\theta$ 系炭化鉄粒子となる．写真 13 は図 $13(\mathrm{~b})$ に対応し た明視野電顕像である.

以上の過程で注目されるのは，析出のごく初期から $\theta-\mathrm{Fe}_{3} \mathrm{C}$ と $\chi-\mathrm{Fe}_{5} \mathrm{C}_{2}$ が microsyntactic intergrowth し た粒子が形成されること, 及びク炭化鉄がかなり安定 で, $\theta$ 系炭化鉄と共存できるということである. 以前 に, その場電子回折研究により, $\varepsilon$ 炭化鉄薄膜は $380^{\circ} \mathrm{C}$ まで安定で，この温度で $\chi$ 炭化鉄に変態すると報告した が26)， $\varepsilon$ と》の類似性を考えると，上述の鉄鋼中におけ るク炭化鉄の安定性にはらなつけるものがある. 


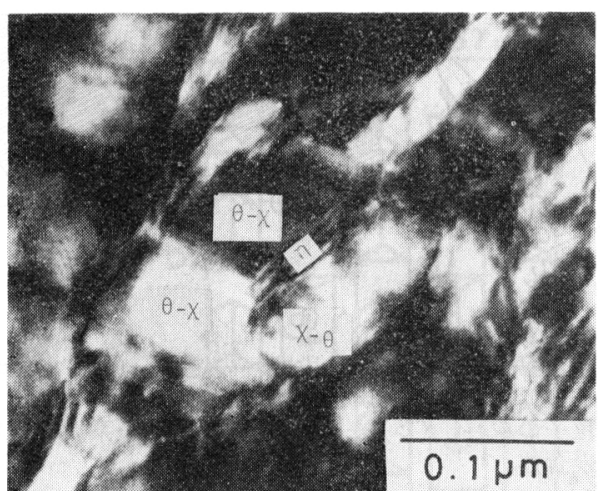

写真 $13200^{\circ} \mathrm{C}$ で筧もどしたマルテンサイト中に見 ら东省折出物の明視野電顕像. $\eta-\mathrm{Fe}_{2} \mathrm{C}$ 粒子の周り 军 $\theta$ 系炭化鉄粒子が取り囲えでいる。 に見られる縞は $\eta-\mathrm{Fe}_{2} \mathrm{C}$ と母相の $\alpha$ 鉄との間の電子 線の二重回折によるモワレ縞.

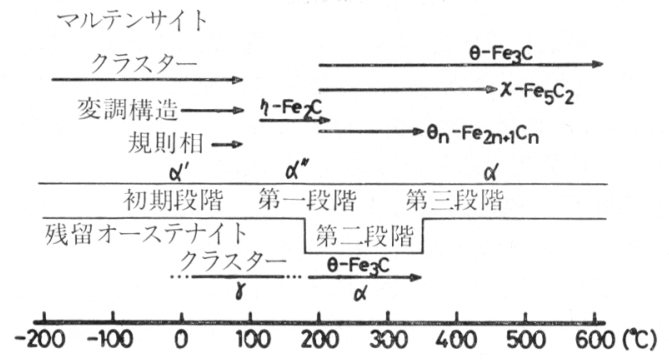

図14 マルテンサイト炭素鋼の焼もどし機構の模式図.

\section{8. 結言}

以上，マルテンサイト炭化鋼の焼もどし機構の電子顕 微鏡・電子回折による研究成果の概要を述べてきたが, これを図 14 にまとめて示す。これにより, 従来必ずし も明確でなからた焼もどし機構が，かなりの程度，確立 されたとい壳よう。

本研究は各温度に打いて生成する構造を確定するのに 主眼点が置かれているので，マルテンサイト鋼の諸物性 との関連については本稿は全くふれていない。しかし, 鉄鋼が，熱処理条件に応じて，その物性に著しい変化を 引き起こすのは, その熱処理に対応した各種組織の出現 によるが, その組織は母相と析出相の種類, 形態, 寸法, 分散状態等によつて定まるので，本稿で示された成果が 鉄鋼の熱処理の進歩に多少なりとも貢献できれば幸いと 思つている.な扐，本研究は1954 年に始められた桶谷 繁雄東京工大名誉教授の金属炭化物の研究の延長線上に あるものであることを付記する。

追記 本稿と内容的に類似のものをすでに他誌に発表 してある ${ }^{28)}$ 。記述の都合上，ある程度の重複はさけられ なかつたことを了承せられたい。

\section{交献}

1) 西山羓次：マルテンサイト变態, 芯用編, 第 4 章 (1974) [丸善]

2 ) 桶谷繁雄, 人見 茂, 長會繁䵇: 日本金属学会誌, 26 (1962), p. 347

3) V. I. Izotov and L. M. Utevskiy : Fiz. Metal. Metallved, 25 (1967), p. 98

4 ) A. G. Khachaturyan and $T$. A. Onisimova: Fiz. Metal. Metallved, 25 (1967), p. 973

5 ) 豊島美智子: 東京工大学位論交 (1980)

6 ) $S$. Nagakura, $K$. Shiraishi, and $Y$. Hirotsu: Trans. JIM, 25 (1975), p. 601

7 ) 弘津禎彦：東京工大学位論交 (1974)

$8)$. Toyoshima and $S$. Nagakura: AIP Conf. Proc. No. 53 (Modulated Structure-1979), p. 263 [Am. Inst. Phys.]

9 ) $M$. Kusunoki (née Toyoshima) and $S$. Nagakura: J. Appl. Crystallogr., 14 (1981), p. 329

10) S. H. Wen, E. Kostran, M. Hong, A. G. Khachaturyan, and $J$. $W$. Morris, Jr.: Acta Metal., 29 (1981), p. 1247

11) $S$. NAgakura and $M$. Toyoshima: Trans. JIM, 20 (1979), p. 100

12) $Y$. Hirotsu, $S$. Nagakura, and $S$. Oketani: Trans. ISIJ, Suppl., 11 (1971), p. 1140

13) $Y$. Hirotsu and $S$. Nagakura: Acta Metal., 20 (1972), p. 655

14) $Y$. Hirotsu and $S$. Nagakura: Trans. JIM, 15 (1974), p. 129

15) $K$. Shimizu and $H$. Окамото: Trans. JIM, 15 (1974), p. 193

16) K. H. JАGK: JISI, 169 (1951), p. 26

17) $Y$. Hirotsu, $Y$. Itakura, $K$. $-G$. Su, and $S$. Nagakura: Trans. JIM, 17 (1976), p. 503

18) $Y$. Tanaka and $K$. Shimizu: Trans. JIM, 22 (1981), p. 779

19）中村吉男，長倉繁魔：日本金属学会秋季講演大会 概要 (1981), p. 305

20) Yu. A. Bagaryatsukil: Dokl. Nauk, SSSR, 73 (1950), p. 1161

21) 中村吉男, 長倉繁麿：日本金属学会秋季講演大会 概要 (1980), p. 167

22) Y. Ohmori: Trans. JIM, 13 (1972), p. 119

23) A. Koreeda and K. Shimizu: Proc. 5-th Internl. Conf. HVEM, Kyoto (1977), p. 611 [日本電子顕微鏡学会]

24) S. Nagakura, T. Suzuki, and $M$. Kusunoki: Trans. JIM, 22 (1981), p. 699

25) $S$. Nagakura, $Y$. Nakamura, and $T$. Suzuki: Jpn. J. Appl. Phys., 21 (1982), p. L 449

26) S. Nagakura: J. Phys. Soc. Jpn, 14 (1959), p. 186

27) 中村吉男，長倉繁魔：日本金属学会春季講演大会 概要 (1982)，p. 42

28) 長倉繁麿，引津禎彦，楠美智子，鈴木俊明，中村 吉男：材料科学，18 (1982), p. 308 